\title{
Extending the rapeseed gene pool with resynthesized Brassica napus II: Heterosis
}

\author{
Andreas Girke • Antje Schierholt $\cdot$ Heiko C. Becker
}

Received: 25 August 2011 / Accepted: 26 November 2011 / Published online: 13 December 2011

(C) The Author(s) 2011. This article is published with open access at Springerlink.com

\begin{abstract}
Hybrid breeding relies on the combination of parents from two differing heterotic groups. However, the genetic diversity in adapted oilseed rape breeding material is rather limited. Therefore, the use of resynthesized Brassica napus as a distant gene pool was investigated. Hybrids were derived from crosses between 44 resynthesized lines with a diverse genetic background and two male sterile winter oilseed rape tester lines. The hybrids were evaluated together with their parents and check cultivars in 2 years and five locations in Germany. Yield, plant height, seed oil, and protein content were monitored, and genetic distances were estimated with molecular markers (127 polymorphic RFLP fragments). Resynthesized lines varied in yield between $40.9 \mathrm{dt} / \mathrm{ha}$ and $21.5 \mathrm{dt} / \mathrm{ha}$, or between 85.1 and $44.6 \%$ of check cultivar yields. Relative to check cultivars, hybrids varied from 91.6 to $116.6 \%$ in yield and from 94.5 to $103.3 \%$ in seed oil content. Mid-parent heterosis varied from -3.5 to $47.2 \%$ for yield. The genetic distance of parental lines was not significantly correlated with heterosis or hybrid yield. Although resynthesized lines do not meet
\end{abstract}

Communicated by R. Visser.

Electronic supplementary material The online version of this article (doi:10.1007/s00122-011-1765-7) contains supplementary material, which is available to authorized users.

Present Address:

A. Girke

Norddeutsche Pflanzenzucht Hans-Georg Lembke KG, Inselstrasse 15, 23999 Malchow/Poel, Germany

A. Schierholt · H. C. Becker $(\square)$

Department of Crop Sciences, Georg August Universität Göttingen, von Siebold Strasse 8, 37075 Göttingen, Germany

e-mail: hbecker1@gwdg.de the elite rapeseed standards, they are a valuable source for hybrid breeding due to their large distance from present breeding material and their high heterosis when combined with European winter oilseed rape.

\section{Introduction}

The potential benefit of heterosis in hybrid breeding programs depends on combining genetically distant gene pools, based on the assumption of a positive correlation between genetic distance (GD) and mid-parent heterosis (Falconer and Mackay 1996). Therefore, the intention of hybrid breeding is to establish genetically distant heterotic groups.

The gene pool of the amphidiploid winter oilseed rape (Brassica napus L.) has its origin in a few interspecific hybridizations between Brassica oleracea and Brassica rapa that occurred spontaneously some centuries ago, and consequently has a narrow basis. Different approaches have been described to extend genetic variation in the B. napus breeding pool with genetically distant material, thereby adding new alleles for agronomic traits.

For example, Kebede et al. (2010) described the broadening of the Canadian spring rapeseed gene pool through introgression of winter rapeseed cultivars. Qian et al. (2006, 2009) suggested the introgression of Chinese semi-winter lines as hybrid parents into the European winter oilseed rape gene pool and Zou et al. (2010) recently discussed intersubgenomic heterosis in B. napus through the partial introgression of subgenomic components from different Brassica species to achieve stronger heterosis.

Becker et al. (1995) used molecular markers to analyze genetic distances between adapted cultivars and resynthesized Brassica napus lines (hereafter referred to as Resyn 
lines), and proposed Resyn lines as a valuable source for broadening the genetic base of the present $B$. napus breeding material in a long-term strategy. Increased seed yield after the introgression of B. napus Resyn lines as hybrid parents into spring rapeseed was described by Girke et al. (2001), Udall et al. (2004), and Seyis et al. (2006).

The general association between hybrid yield, heterosis, and GD based on molecular markers in oilseed rape has been discussed previously (Knaak and Ecke 1995; Diers et al. 1996) and has been closely examined in other hybrid crops such as maize (Melchinger 1999; Reif et al. 2010).

Analyses of 142 B. napus Resyn lines by molecular markers have revealed that the majority of Resyn lines were outside the genetic diversity of the worldwide breeding material, including winter, semi-winter (Asian), and spring types (Girke et al. 2011). In the present study, 44 of these 142 Resyn lines were crossed with two male sterile winter oilseed rape tester lines, and hybrids were tested in five environments for 2 years.

The objectives of this study were to (1) evaluate the agronomic potential of hybrids derived from crosses between Resyn lines and winter oilseed rape cultivars; (2) analyze the relation between GD and heterosis; and (3) discuss how a gene pool of Resyn lines can be utilized in the breeding of European winter oilseed rape hybrids.

\section{Materials and methods}

Germplasm and hybrid seed production

Resyn line preselection took place in field trials from 1995 to 1997 , at Reinshof station near Göttingen. Forty-four B. napus Resyn lines (Table 1) were preselected for basic agronomic characteristics, including general disease resistance, growth type, lodging, seed set, winter-hardiness, and for flowering time that matched with adapted winter rapeseed material. The Resyn lines' origin and parental lines varied strongly (Online Resource 1). Only a few lines shared a parent, for example, H113, H80/30, and R8 had the same maternal parent cultivar (B. oleracea convar. capitata var. sabauda 'Eisenkopf'), and three other Resyn lines had B. rapa ssp. pekinensis 'Tip Top Nr.12' as the paternal parent. The use of subspecies of B. oleracea as the maternal parent and of $B$. rapa as the paternal parent predominated, although in a few Resyn lines it was the other way around (for example, S3, S13, and S9). In three lines (H30, H111/ 2, and K306), B. napus ssp. napus var. pabularia 'Siberian Kale' was used as the corresponding paternal parent instead of a $B$. oleracea subspecies.

The Male Sterile Lembke (MSL) lines, MSL004 and MSL007, were used as tester lines in hybrid development. MSL004 and MSL007 were developed by Norddeutsche
Pflanzenzucht Hans-Georg Lembke KG from the cultivars Falcon and Express, respectively. It had been demonstrated previously (Girke et al. 2011) that the sterile lines are genetically closely related to the corresponding cultivars. Therefore, the sterile tester lines are referred to as Falconms and Express-ms throughout this study. The agronomic characteristics of Falcon-ms and Express-ms varied significantly $(P=0.05)$ in oil content $(42.2$ and $44.0 \%$, respectively) and plant height (166 and $148 \mathrm{~cm}$, respectively), but no significant differences were observed in protein content (19.8 and $19.9 \%$, respectively).

The hybrid seed from the crosses of Resyn lines with male sterile lines Falcon-ms and Express-ms was produced in $9 \mathrm{~m}^{2}$ isolation cabins at the Reinshof station near Göttingen in the years 1997-1998 and 1998-1999. The male parental Resyn line was sown in the center double row of the isolation cabin, flanked by two double rows sown with the male sterile tester lines Falcon-ms and Express-ms. Red mason bees (Osmia rufa) were used as pollinators and added to the isolation cabins at the beginning of flowering. $F_{1}$ hybrid seeds and selfed seeds of the Resyn father line were harvested separately in each cabin.

Field trials and statistical analyses

The genotypes were tested for 2 years (1998-1999 and 1999-2000) at five locations in northern and central Germany (Einbeck, Göttingen, Hohenlieth, Teendorf, and Thüle) in a lattice design with two replications. The winter oilseed rape cultivars Express, Falcon, Mohican (both years), Joker (in 1998-1999), and Pronto (in 1999-2000) were used as check cultivars. Express, Falcon, and Mohican were line cultivars; Joker and Pronto were among the very first MSL-hybrids at that time, and they were both released in 1995 (Becker et al. 1999).

Plot sizes differed from 11.25 to $17.5 \mathrm{~m}^{2}$. Parental Resyn lines and their hybrids with Falcon-ms and Express-ms were tested in three separate trials per location to avoid interplot competition effects, because the test of the unadapted genotypes together with hybrids in a single trial would favor the hybrids over the comparatively weakergrowing Resyn lines and consequently underestimate the latter. In 1998-1999, four Express-ms hybrids were included in the trial of Falcon-ms hybrids. In 1999-2000, Resyn lines were only tested in three locations (Hohenlieth, Göttingen, and Teendorf). Because of seed shortage, not all lines and hybrids were tested in both years (Table 1).

Maximum plant height $(\mathrm{cm})$ at the end of flowering and yield (dt/ha) were recorded in the field trials. As quality parameters of the harvested seeds, their oil (\% dry matter), protein (\% dry matter), and glucosinolate (GSL; $\mu \mathrm{mol} / \mathrm{g}$ degreased seed meal) contents were measured using nearinfrared reflectance spectroscopy (NIRS; Tillmann 1997). 
Table 1 Absolute and relative observed performance of 44 Resyn lines

\begin{tabular}{|c|c|c|c|c|c|c|c|c|c|}
\hline \multirow{2}{*}{$\begin{array}{l}\text { Trial } \\
\left(1998-1999^{a}\right)\end{array}$} & \multirow{2}{*}{$\begin{array}{l}\text { Trial } \\
\left(1999-2000^{\mathrm{a}}\right)\end{array}$} & \multicolumn{2}{|c|}{ Resyn line } & \multirow{2}{*}{$\begin{array}{l}\text { Yield } \\
\text { (dt/ha) }\end{array}$} & \multirow{2}{*}{$\begin{array}{l}\text { Oil } \\
(\%)\end{array}$} & \multirow{2}{*}{$\begin{array}{l}\text { Protein } \\
(\%)\end{array}$} & \multirow{2}{*}{$\begin{array}{l}\text { GSL } \\
(\mu \mathrm{mol} / \mathrm{g})\end{array}$} & \multirow{2}{*}{$\begin{array}{l}\text { Plant } \\
\text { height }(\mathrm{cm})\end{array}$} & \multirow{2}{*}{$\begin{array}{l}\text { Yield } \\
\left(\% \text { of checks }{ }^{b}\right)\end{array}$} \\
\hline & & Nr. & Name & & & & & & \\
\hline REF & REF & 1 & H48 & 40.9 & 39.3 & 21.2 & 55.3 & 146 & 85.1 \\
\hline $\mathrm{RF}$ & REF & 2 & G65 & 38.5 & 41.1 & 22.3 & 54.1 & 166 & 80.0 \\
\hline $\mathrm{RE}$ & REF & 3 & L239 & 38.2 & 39.7 & 22.1 & 44.4 & 177 & 79.5 \\
\hline RE & REF & 4 & S3 & 36.5 & 42.1 & 22.4 & 84.9 & 163 & 75.8 \\
\hline RF & REF & 5 & H149a & 35.0 & 39.8 & 22.6 & 66.4 & 153 & 72.7 \\
\hline REF & REF & 6 & S12 & 34.1 & 39.9 & 21.6 & 47.2 & 170 & 70.8 \\
\hline REF & REF & 7 & $\mathrm{H} 4$ & 32.4 & 40.4 & 22.5 & 34.4 & 172 & 67.3 \\
\hline REF & REF & 8 & H94 & 30.8 & 39.3 & 21.6 & 67.5 & 157 & 64.1 \\
\hline $\mathrm{R}$ & REF & 9 & H196 & 31.3 & 40.5 & 22.8 & 43.0 & 171 & 65.0 \\
\hline REF & REF & 10 & L16 & 32.0 & 40.5 & 23.0 & 54.7 & 161 & 66.4 \\
\hline $\mathrm{R}$ & REF & 11 & G89 & 32.3 & 41.1 & 21.5 & 33.1 & 164 & 67.1 \\
\hline REF & REF & 12 & S13 & 31.4 & 41.7 & 21.8 & 81.9 & 162 & 65.2 \\
\hline REF & REF & 13 & S9 & 30.2 & 42.5 & 21.4 & 64.7 & 167 & 62.9 \\
\hline $\mathrm{RE}$ & REF & 14 & H143 & 30.4 & 39.1 & 23.7 & 52.7 & 157 & 63.3 \\
\hline REF & REF & 15 & R98 & 30.1 & 39.0 & 23.7 & 77.5 & 160 & 62.6 \\
\hline $\mathrm{RE}$ & REF & 16 & $\mathrm{R} 53$ & 29.1 & 41.8 & 22.2 & 44.8 & 160 & 60.5 \\
\hline $\mathrm{RE}$ & REF & 17 & $\mathrm{~S} 31$ & 26.9 & 39.9 & 23.5 & 76.2 & 146 & 55.9 \\
\hline RE & REF & 18 & R59 & 27.2 & 39.8 & 23.0 & 78.6 & 155 & 56.5 \\
\hline REF & REF & 19 & H295 & 21.6 & 39.6 & 23.7 & 45.5 & 152 & 45.0 \\
\hline \multirow[t]{4}{*}{$\mathrm{RE}$} & REF & 20 & $\mathrm{H} 280$ & 21.5 & 39.1 & 23.1 & 69.0 & 150 & 44.6 \\
\hline & & & Mean & 31.5 & 40.3 & 22.5 & 58.8 & 160 & 65.5 \\
\hline & & & Checks ${ }^{\mathrm{b}}$ Mean & 48.1 & 43.0 & 19.5 & 16.6 & 162 & 100 \\
\hline & & & $\operatorname{Lsd}(0.05)^{\mathrm{c}}$ & 2.6 & 1.6 & 0.9 & 7.8 & 8 & 9.5 \\
\hline REF & & 21 & H176 & 39.5 & 43.6 & 19.9 & 41.4 & 159 & 80.3 \\
\hline REF & & 22 & $\mathrm{H} 30$ & 36.8 & 40.9 & 20.6 & 59.4 & 148 & 74.8 \\
\hline REF & & 23 & H128 & 31.1 & 42.0 & 21.3 & 31.4 & 148 & 63.2 \\
\hline REF & $\mathrm{EF}$ & 24 & S27 & 30.4 & 39.9 & 21.8 & 44.8 & 141 & 61.8 \\
\hline REF & $\mathrm{EF}$ & 25 & H65 & 29.0 & 43.1 & 20.7 & 47.8 & 131 & 58.9 \\
\hline $\mathrm{RF}$ & $\mathrm{EF}$ & 26 & S35 & 27.0 & 40.9 & 21.6 & 39.9 & 142 & 54.9 \\
\hline REF & & 27 & H111/2 & 26.5 & 40.5 & 21.2 & 74.8 & 150 & 53.9 \\
\hline REF & $\mathrm{EF}$ & 28 & S29 & 20.5 & 42.5 & 21.9 & 65.1 & 151 & 41.7 \\
\hline $\mathrm{RE}$ & $\mathrm{EF}$ & 29 & $\mathrm{H} 80 / 3$ & 18.3 & 37.5 & 24.0 & 74.4 & 132 & 37.2 \\
\hline REF & $\mathrm{EF}$ & 30 & G39 & 14.7 & 39.6 & 21.5 & 51.1 & 135 & 29.9 \\
\hline $\mathrm{R}$ & $\mathrm{EF}$ & 31 & H165 & 10.9 & 38.6 & 23.2 & 58.4 & 121 & 22.2 \\
\hline \multirow[t]{4}{*}{$\mathrm{RE}$} & $\mathrm{EF}$ & 32 & K306 & 8.2 & 39.8 & 22.4 & 55.8 & 113 & 16.7 \\
\hline & & & Mean & 24.4 & 40.7 & 21.7 & 53.7 & 139.3 & 49.6 \\
\hline & & & Checks $^{\text {b }}$ Mean & 53.3 & 43.7 & 18.1 & 15.4 & 165 & 100 \\
\hline & & & $\operatorname{Lsd}(0.05)^{\mathrm{c}}$ & 7.5 & 1.8 & 1.5 & 9.7 & 15 & 14.7 \\
\hline \multirow[t]{2}{*}{$\mathrm{E}$} & REF & 33 & $\mathrm{RS} 1 / 2$ & 44.6 & 41.0 & 22.1 & 50.4 & 178 & 90.7 \\
\hline & REF & 34 & H226 & 36.1 & 41.9 & 22.6 & 41.2 & 160 & 73.4 \\
\hline $\mathrm{F}$ & REF & 35 & $\mathrm{H} 40$ & 35.9 & 39.9 & 22.7 & 59.5 & 167 & 73.0 \\
\hline $\mathrm{EF}$ & REF & 36 & $\mathrm{~S} 30$ & 35.2 & 39.8 & 22.5 & 45.2 & 164 & 71.5 \\
\hline $\mathrm{E}$ & REF & 37 & $\mathrm{R} 140$ & 34.2 & 40.1 & 23.1 & 50.6 & 161 & 69.5 \\
\hline $\mathrm{E}$ & REF & 38 & S101 & 32.9 & 40.9 & 23.9 & 59.4 & 168 & 66.9 \\
\hline \multirow[t]{2}{*}{$\mathrm{EF}$} & REF & 39 & H89 & 31.2 & 38.1 & 26.3 & 68.2 & 139 & 63.4 \\
\hline & REF & 40 & L35 & 28.8 & 41.5 & 23.6 & 33.4 & 167 & 58.5 \\
\hline
\end{tabular}


Table 1 continued

\begin{tabular}{|c|c|c|c|c|c|c|c|c|c|}
\hline \multirow{2}{*}{$\begin{array}{l}\text { Trial } \\
\left(1998-1999^{a}\right)\end{array}$} & \multirow{2}{*}{$\begin{array}{l}\text { Trial } \\
\left(1999-2000^{\mathrm{a}}\right)\end{array}$} & \multicolumn{2}{|c|}{ Resyn line } & \multirow{2}{*}{$\begin{array}{l}\text { Yield } \\
\text { (dt/ha) }\end{array}$} & \multirow{2}{*}{$\begin{array}{l}\text { Oil } \\
(\%)\end{array}$} & \multirow{2}{*}{$\begin{array}{l}\text { Protein } \\
(\%)\end{array}$} & \multirow{2}{*}{$\begin{array}{l}\text { GSL } \\
(\mu \mathrm{mol} / \mathrm{g})\end{array}$} & \multirow{2}{*}{$\begin{array}{l}\text { Plant } \\
\text { height }(\mathrm{cm})\end{array}$} & \multirow{2}{*}{$\begin{array}{l}\text { Yield } \\
\left(\% \text { of checks }{ }^{b}\right)\end{array}$} \\
\hline & & $\mathrm{Nr}$. & Name & & & & & & \\
\hline $\mathrm{F}$ & REF & 41 & $\mathrm{R} 1$ & 28.1 & 38.2 & 24.7 & 49.5 & 155 & 57.1 \\
\hline $\mathrm{EF}$ & REF & 42 & H113 & 27.2 & 40.9 & 24.1 & 86.9 & 161 & 55.3 \\
\hline F & REF & 43 & R8 & 25.0 & 40.5 & 24.1 & 71.6 & 143 & 50.8 \\
\hline \multirow[t]{4}{*}{ E } & REF & 44 & H219 & 15.4 & 38.7 & 24.4 & 42.9 & 141 & 31.3 \\
\hline & & & Mean & 31.2 & 40.1 & 23.7 & 54.9 & 158.7 & 63.5 \\
\hline & & & Checks ${ }^{\mathrm{b}}$ Mean & 46.3 & 42.2 & 20.8 & 17.9 & 160 & 100 \\
\hline & & & $\operatorname{Lsd}(0.05)^{\mathrm{c}}$ & 4.5 & 2.5 & 1.3 & 5.9 & 10 & 9.8 \\
\hline
\end{tabular}

Mean values from five locations in 1998-1999 and three locations in 1999-2000. At the Einbeck location, only seed yield was determined. Mean values and least significant differences (Lsd) of check cultivars are included

a Genotypes tested in field trials as: $R$ Resyn line, $E$ hybrid with Express-ms, $F$ hybrid with Falcon-ms

b Cultivars evaluated as checks in 1998-1999 and 1999-2000: Express, Falcon, Mohican; Joker (only in 1998-1999), and Pronto (only in 19992000)

${ }^{\mathrm{c}}$ Lsd (0.05); least significant difference at $P=0.05$

In this study, the GSL content was presented only for Resyn lines (Table 1). At the Einbeck location, only seed yield was determined.

The statistical analyses of all field trials, estimations of correlations, least significant differences (Lsd), and tests of significance were performed using PLABSTAT software (Utz 1991). Mean values, degrees of freedom (df), and standard error (SE) were extracted from the analyses of the individual trials and integrated into a combined analysis of variance (ANOVA). The ANOVA of the field trials was calculated separately for both years, because of differences in the testing set of genotypes, with the following model: $Y_{i j n}=\mu+\mathrm{g}_{i}+\mathrm{e}_{j}+(\mathrm{ge})_{i j}+\varepsilon_{i j n}$, where $Y_{i j n}$ is defined as the observation of genotype $g$ at environment $\mathrm{e}$ and replication $n, \mu$ is the overall mean, $\mathrm{g}_{i}$ is the effect of genotype $\mathrm{g}$ (for $i=1, \ldots, 49$ ), $\mathrm{e}_{j}$ is the effect of environment 1 (for $j=1, \ldots$, $5)$, (ge $)_{i j}$ is the corresponding interaction effect, and $\varepsilon_{i j n}$ is the experimental error. The ANOVA was calculated as mixed model, where the effect of the location was considered random and the effect of the genotype was considered fixed.

Because not all Resyn lines and corresponding hybrids were tested orthogonally at five locations and in 2 years, the data set for the estimation of heterosis and parental mean of the hybrids is based on either 1-year or 2-year results (Table 1), and hybrid yield and heterosis were presented as percentages of the mean of the check cultivars, which were integrated into all trials.

Heterosis was estimated as mid-parent heterosis, with the overall mean yield of cultivars Express and Falcon, which were integrated as check cultivars in all trials, defined as the respective female parent. The mean values of Express and Falcon differed significantly $(P=0.05)$ regarding seed yield in the trials of Resyn lines ( $42.6 \mathrm{dt} / \mathrm{ha})$ and hybrids ( 40.2 and $40.4 \mathrm{dt} / \mathrm{ha}$ in the trials of Express and Falcon hybrids, respectively). The mean values of Express and Falcon in all three trials were used to estimate yield heterosis.

Molecular marker and genetic distance analyses

A detailed description of DNA extraction, molecular marker analyses, and estimation of GD and principle coordinates was provided previously by Girke et al. (2011). Briefly summarized, the estimations of GD were based on the similarity index of Dice (1945), which was calculated using 127 polymorphic RFLP fragments. All statistical analyses were performed using NTSYS-pc 2.1 software (Rohlf 2000).

\section{Results}

\section{Analysis of variance}

For both the Resyn lines and their hybrids, genotype was a significant source of variation $(P=0.01)$ for all traits in both trial years except for the seed yield of Falcon-ms hybrids, for which the differences were only significant in 1999-2000 (Table 2). Environment was the largest source of variation and affected all traits significantly $(P=0.01)$. The genotype $\times$ environment interaction was significant for most traits in 1998-1999 and for all traits in 1999-2000. For Express hybrids, genotypic variance components for yield varied between 10.3 in 1998-1999 and 1.5 in 19992000. For Falcon hybrids, genotypic variance components for yield varied between 1.9 in 1998-1999 and 0.7 in 19992000. By comparison, these variance components were 


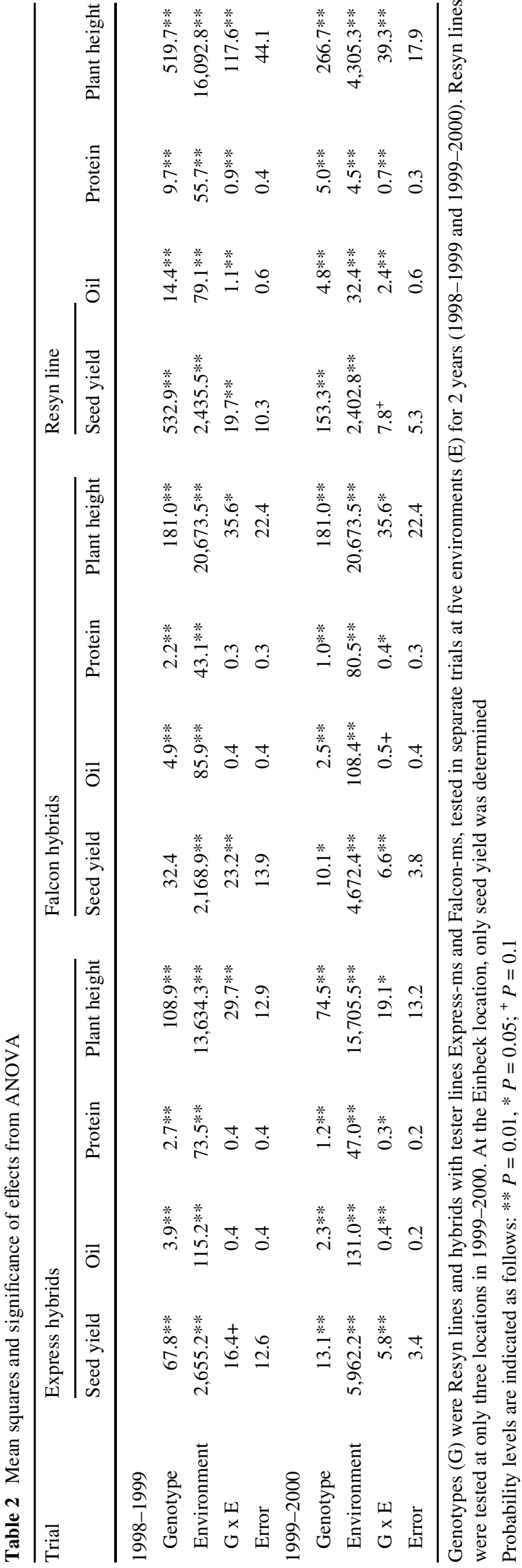

much larger for the Resyn lines: 102.2 in 1998-1999 and 48.5 in 1999-2000 (data not shown in Table 2).

Resyn lines: performance

The Resyn lines varied in seed yield from $8.2 \mathrm{dt} / \mathrm{ha}$ for K306 (only tested in 1998-1999; Table 1) to $44.6 \mathrm{dt} / \mathrm{ha}$ for RS1/2 (tested in 1999-2000). Of the Resyn lines tested in both years, $\mathrm{H} 48$ demonstrated the highest absolute yield $(40.9 \mathrm{dt} /$ ha) and relative yield ( $85.1 \%$ of the check cultivar yields). Oil content in the Resyn lines ranged from 37.5 (H80/3) to $43.6 \%$ (H176); both of these lines were tested only in 19981999. Of Resyn lines with 2-year data, S9 had the highest oil content $(42.5 \%)$. Yield and oil content were correlated positively with each other $(P=0.01, r=0.53)$ and negatively with protein content $(P=0.01 ; r=-0.72$ and $r=-0.71$, respectively). The protein content of all Resyn lines was higher than the mean of the check cultivars. The GSL content of all Resyn lines was not nearly as low as the canola oil quality standard; the best line (H128) contained $31.4 \mu \mathrm{mol} / \mathrm{g}$ GSL. The Resyn lines varied in plant height from 113 (K306) to $178 \mathrm{~cm}(\mathrm{RS} 1 / 2)$. Plant height correlated significantly $(P=0.01)$ and positively with seed yield and oil content ( $r=0.74$ and $r=0.61$, respectively), and negatively with protein content $(r=-0.70)$.

\section{Hybrid yield and heterosis}

Yield, oil content, protein content, and plant height of the hybrids are reported as percentages of the respective means of check cultivar parameters (Table 3; Fig. 1). The relative mean yield of the hybrids was higher than the mean yield of check cultivars in both tester combinations. The maximum relative hybrid seed yield observed was $116.6 \%$ in Expressms and $110.8 \%$ in Falcon-ms hybrids. Both highest-yielding hybrids had H48 (one of the Resyn lines with the highest line per se performance) as the pollinator, which resulted from a cross of Savoy with Chinese cabbage. The minimum yield was observed in hybrids derived from crosses of Express-ms with S27 (91.6\%) and Falcon-ms with H111/2 (92.3\%), both Resyn lines had a comparatively low yield.

Oil content did not vary as greatly as yield and the mean hybrid oil content was below the mean of the check cultivars in both test cross series. The highest absolute and relative oil contents were observed in hybrids of S9 with Express-ms (absolute 44.4\%; relative 103\%), as well as with Falcon-ms (absolute 43.8\%; relative $102.4 \%$ ). S9 was one of the Resyn lines with the highest seed oil content (Table 1) and originated from a cross of Chinese cabbage with Brussels sprouts.

The mean protein content and plant height of both test cross series exceeded the respective means of check cultivars. 
Table 3 Mean relative hybrid yield (expressed as percentage of check cultivars) and relative heterosis (\%) of hybrids with tester lines Expressms and Falcon-ms evaluated in 1998-1999 and in 1999-2000

\begin{tabular}{|c|c|c|c|c|c|c|c|c|}
\hline & \multicolumn{4}{|c|}{ Express hybrids } & \multicolumn{4}{|c|}{ Falcon hybrids } \\
\hline & Yield & Oil & Protein & Plant height & Yield & Oil & Protein & Plant height \\
\hline \multicolumn{9}{|c|}{ Hybrid yield (\%) } \\
\hline Minimum & 91.6 & 95.3 & 102.2 & 100.0 & 92.3 & 94.5 & 99.5 & 103.7 \\
\hline Maximum & 116.6 & 103.3 & 114.2 & 112.2 & 110.8 & 102.4 & 111.4 & 115.0 \\
\hline Mean & 104.9 & 98.8 & 107.4 & 104.2 & 101.8 & 97.6 & 105.0 & 107.8 \\
\hline $\operatorname{Lsd}(0.05)^{\mathrm{a}}$ & 11.3 & 2.3 & 5.0 & 4.0 & 9.7 & 2.4 & 4.2 & 4.1 \\
\hline \multicolumn{9}{|l|}{ Heterosis (\%) } \\
\hline Minimum & -3.5 & -1.9 & -13.4 & 2.0 & 2.6 & -2.0 & -16.8 & 0.5 \\
\hline Maximum & 47.2 & 4.6 & 3.8 & 20.3 & 44.9 & 6.0 & 1.9 & 20.4 \\
\hline Mean & 22.3 & 0.5 & -2.5 & 8.6 & 23.9 & 1.7 & -4.0 & 7.0 \\
\hline
\end{tabular}

Not all hybrids were tested in both years (see Table 1)

${ }^{\text {a }}$ Lsd (0.05); least significant difference at $P=0.05$

The relative seed yields of the two test cross series were correlated positively $(r=0.5, P=0.01$; Fig. 2$)$. In both tester combinations, most of the hybrids surpassed the mean of check cultivars regarding seed yield (Fig. 1). Notably, the highest-yielding hybrids had both lower-yielding and higher-yielding Resyn lines as parental lines.

Regarding seed yield, heterosis varied in both test cross combinations from -3.5 to $47.2 \%$ for Express-ms hybrids and from 2.6 to $44.9 \%$ for Falcon-ms hybrids (Table 3). In particular, high heterosis was observed in many hybrids of Resyn lines with a low yield (for example, K306; Fig. 1).

Genetic distances and correlations

The mean GD in the group of 44 Resyn lines was 0.327 (range 0.11-0.52) and the GD between Falcon-ms and Express-ms tester lines, and Resyn lines differed as a result (Fig. 3). The hybrids with the highest and lowest GD between their parental lines are, with respect to hybrid yield and heterosis, evenly distributed among the group of 44 hybrids (Fig. 1).

The correlations for hybrid yield, heterosis, GD, and parental mean varied (Table 4) for seed yield and agronomic parameters. For both the Express-ms and Falcon-ms hybrids, GD and hybrid seed yield $(r=-0.10$ and $r=-0.23$, respectively), and GD and heterosis $(r=-0.16$ and $r=-0.36$, respectively) were negatively and weakly correlated. The parental mean and hybrid seed yield were positively correlated, while parental mean and heterosis were significantly negatively correlated $(r=-0.67$ and $r=-0.83$, respectively). Finally, there was a positive and significant correlation between heterosis and hybrid seed yield (Express-ms hybrids $r=0.46$; Falcon-ms hybrids $r=0.32$ ). For oil content, protein content, and plant height, mostly stronger and positive correlations were estimated for parental mean and hybrid yield, while the correlations of parental mean and heterosis were negative (Table 4).

\section{Discussion}

Resyn lines: evaluation and use in breeding

Despite the fact that the Resyn lines had been preselected for agronomic adaptation, the evaluation of the seed yields of Resyn lines was complicated by lodging, deviating flowering times, and higher susceptibility to diseases, mainly blackleg (Phoma lingam). There were no plant losses during the winter, but the winters of 1998 and 1999 were relatively mild. Some years later, in the winter of 2002-2003, several lines did not survive at all (data not shown), corroborating the general observation that Resyn lines often demonstrate poor winter-hardiness.

The low seed yields of the Resyn lines correspond to findings from Girke et al. (2001), which reported an average yield decrease of $40 \%$ for spring B. napus Resyn lines compared with adapted cultivars. Another problem with the use of Resyn lines in hybrid breeding is their seed oil quality, which does not comply with canola standards. The use of parental lines with the desired canola seed quality (zero erucic acid, low GSL content), such as B. rapa ssp. oleifera, to design Resyn lines with presumably better seed oil quality has been discussed previously. Rygulla et al. (2007) described zero erucic acid Resyn lines derived from crosses of a zero erucic acid cabbage mutant (B. oleracea convar. capitata 'Kashirka 202') with zero erucic acid spring turnip varieties. While erucic acid and GSL content are inherited by relatively few and mostly known genes, the inheritance of oil content is much more complex. Although cultivar Express is known for its high oil content, the mean oil 

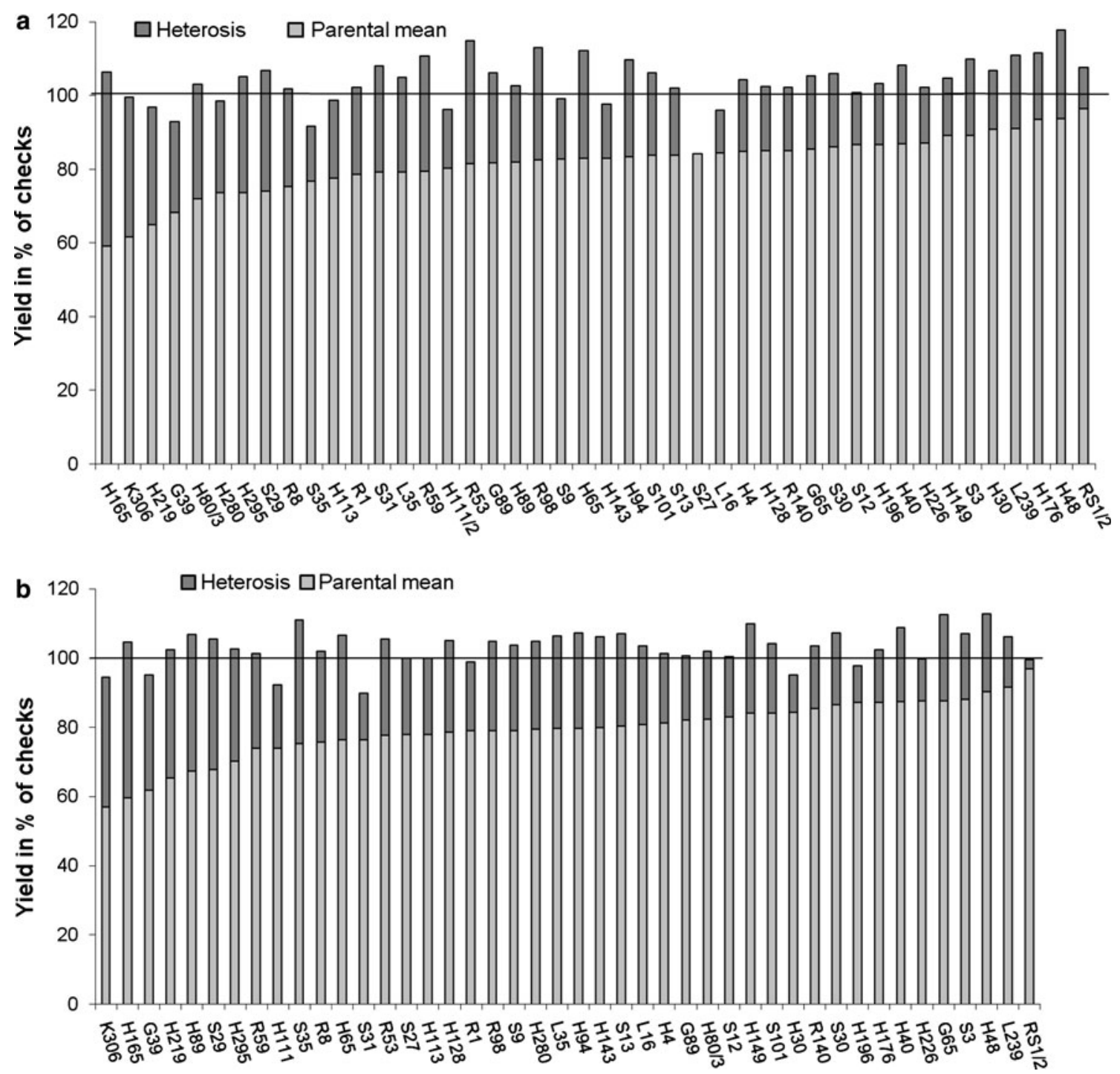

Fig. 1 Hybrid yield, parental mean, and heterosis of a Express hybrids and $\mathbf{b}$ Falcon hybrids with Resyn lines, expressed as percentage of check cultivars $(100 \%=$ mean value of check cultivars $)$

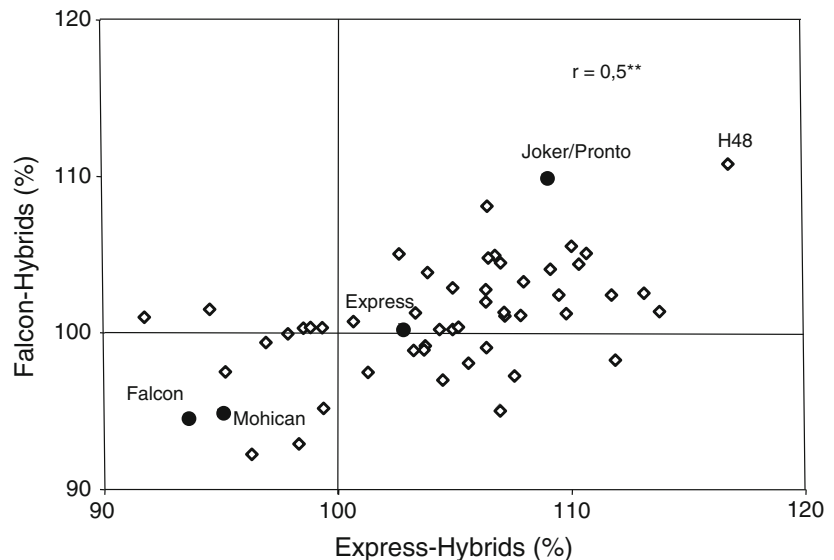

Fig. 2 Correlations of the relative seed yields of hybrids of Resyn lines with Falcon-ms and with Express-ms. 100\% = mean value of check cultivars content of Express hybrids did not reach the mean level of the check cultivars (Table 3). Some Express hybrids exceeded the mean level of check cultivars; however, only one Express hybrid in a single year surpassed Express. This hybrid had S9 as pollinator, the Resyn line with the highest observed oil content (Table 1). Therefore, the generally low seed oil content of the Resyn lines is a major challenge.

Heterosis and hybrid yield

Mean mid-parent heterosis was high: $22.3 \%$ for Express hybrids and 23.9\% for Falcon hybrids (Table 3), compared with earlier studies examining European winter oilseed rape. Léon (1991) and Knaak and Ecke (1995), respectively, observed 15 and $16.9 \%$ heterosis for seed yield. LefortBuson et al. (1987) described $12 \%$ heterosis for crosses in 


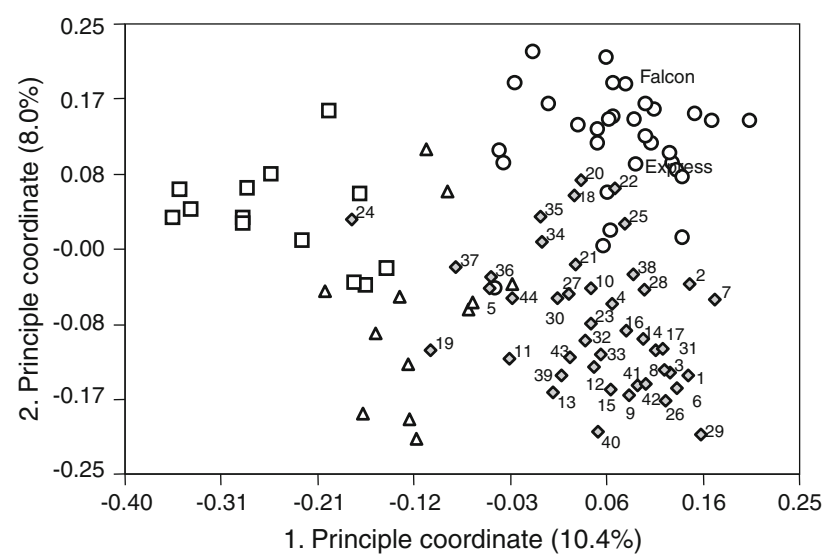

Fig. 3 Principle coordinate analysis of 44 Resyn lines and 57 B. napus genotypes of Asian and European origin, including the tester lines Falcon-ms and Express-ms. Symbols represent winter type (circles), spring type (squares), semi-winter (Asian) type (triangles), and Resyn lines (diamonds)

the European winter oilseed rape gene pool and 39.5\% heterosis for interpool hybrids with Asiatic germplasm. The low line per se performance of some unadapted Resyn lines in this study, such as K306 and H165, could have created an overestimation of heterosis in the hybrids, while hybrid yield can be considered a more stable parameter.

A number of hybrids had higher yields than the mean yield of check cultivars, which indicates the existence of alleles that contribute positively to combining ability for yield in this relatively small and not intensively preselected group of Resyn parental lines. The highest-yielding hybrids resulted from crosses of Resyn lines, which themselves can have high or low yields, and the correlation between parental mean and hybrid yield was weak. The genetic background of the hybrids with the highest yield differed between both test cross series, with the exception of Resyn line H48, which was the pollinator of the highest-yielding hybrid of both series. Resyn line $\mathrm{H} 48$ has the same maternal parent (B. oleracea convar. capitata var. sabauda Vorbote) as Resyn lines H80/30 and H219; however, the latter are not noted for high yield. The Resyn pollinator lines of the highest-yielding hybrids with Falcon-ms (H48, G65, H149, and S35) and Express-ms (H48, R53, R98, and H65) did not have any obvious similarities regarding their B. oleracea or B. rapa parental genotypes or subspecies.

Correlations of GD, heterosis, and hybrid yield

In this study, no close correlation was observed between hybrid seed yield, heterosis, and the GD of the parental lines of resulting hybrids. This finding is in accordance with Girke et al. (2001), who did not observe a corresponding correlation in a study on spring type B. napus Resyn lines and hybrids. Diers et al. (1996) detected a correlation between GD and hybrid yield $(r=0.58)$, but no correlation with heterosis in spring rapeseed germplasm. In contrast, Knaak and Ecke (1995) observed a significant and close correlation $(r=0.72)$ between GD and heterosis, but not with hybrid yield, in winter oilseed rape. However, Riaz et al. (2001) described a significant correlation between the GD of inbred lines and their hybrid performance $(r=0.64)$, as well as mid-parent heterosis $(r=0.63)$ in hybrids of ten spring rapeseed lines. Qian et al. (2009) described a weak negative correlation between GD and seed yield $(r=-0.10)$ among hybrids derived from crosses between 14 Chinese semi-winter type lines and four male sterile winter oilseed rape lines.

Contradictory results regarding correlations between GD and heterosis in inter- and intra-group crosses are discussed by Melchinger (1999), who summarized the results of several studies in different species. He concluded that correlations between GD and heterosis only occur in materials with differences in coancestry, and not in inter-group crosses between parents from genetically diverse heterotic groups.

Based on the model of Melchinger (1999), Resyn lines that were selected for their GD from the tester would not promise higher heterosis per se. This hypothesis is corroborated here not only by the low correlation of GD between parental lines and heterosis of the hybrids, but also by the

Table 4 Correlations $(r)$ of hybrid yield, heterosis, genetic distance (GD), and parental mean for the parameters seed yield, seed oil content, protein content, and plant height of hybrids with Express-ms and Falcon-ms

\begin{tabular}{|c|c|c|c|c|c|c|c|c|c|}
\hline \multirow[t]{2}{*}{ Parameter } & \multirow[t]{2}{*}{ Hybrid } & \multicolumn{2}{|l|}{ Seed yield } & \multicolumn{2}{|l|}{ Oil content } & \multicolumn{2}{|c|}{ Protein content } & \multicolumn{2}{|l|}{ Plant height } \\
\hline & & Hybrid yield & Heterosis & Hybrid yield & Heterosis & Hybrid yield & Heterosis & Hybrid yield & Heterosis \\
\hline \multirow[t]{2}{*}{ GD } & Express & -0.10 & -0.16 & -0.01 & -0.10 & -0.12 & 0.28 & -0.18 & -0.03 \\
\hline & Falcon & -0.23 & $-0.36^{*}$ & -0.22 & $-0.52 * *$ & -0.02 & $0.42 * *$ & 0.03 & 0.09 \\
\hline \multirow[t]{2}{*}{ Parental mean } & Express & $0.34 *$ & $-0.67 * *$ & $0.69 * *$ & -0.28 & $0.65 * *$ & $-0.60 * *$ & $0.44 * *$ & $-0.83 * *$ \\
\hline & Falcon & 0.28 & $-0.83 * *$ & $0.60 * *$ & $-0.46^{* *}$ & $0.32 *$ & $-0.59 * *$ & 0.28 & $-0.86 * *$ \\
\hline \multirow[t]{2}{*}{ Heterosis } & Express & $0.46 * *$ & - & $0.50 * *$ & - & 0.22 & - & 0.13 & - \\
\hline & Falcon & $0.32 *$ & - & $0.44 * *$ & - & $0.58 * *$ & - & 0.25 & - \\
\hline
\end{tabular}

*, ** Significant for $P=0.05$ and 0.01 , respectively 
even distribution of hybrids with a high GD (such as H295, H80/3, G89, and R98) and with a low GD (such as H280, $\mathrm{H} 40, \mathrm{H} 65$, and S30), which demonstrated both high and low heterosis (Fig. 1).

Perhaps the use of oilseed, instead of vegetable or biomass-type parental subspecies, would lead to Resyn lines with a higher seed yield. It was not the aim of this study to analyze this possibility; however, the genetic backgrounds of the Resyn lines are known: 9 out of 44 Resyn parental lines have B. rapa ssp. oleifera as either a maternal (2) or paternal (7) parent and 3 of these Resyn lines (G39, R59, and S35) share the parent 'Yellow seeds/2009' (Online Resource 1). None of these were outstanding or formed a cluster, in line per se performance, parental mean, heterosis, or hybrid yield of their corresponding hybrids (Table 1; Fig. 1).

The genetic stability of amphidiploid resynthesized B. napus has recently been discussed by Gaeta et al. (2007) and Szadkowski et al. (2010). In our material, we did not observe any evidence for instability in meiosis or fertility problems as a consequence of the restructuring of merged genomes. Most of the Resyn lines in this study have been propagated in the field for some generations and were preselected for agronomic performance and seed set. Nevertheless, before using Resyn lines in commercial hybrid breeding programs, their genomic stability must be affirmed.

\section{Conclusions}

The use of Resyn lines in B. napus hybrid breeding is very interesting, because they represent genetic diversity outside of the worldwide breeding material in this species. This is supported by the high amount of yield heterosis observed in hybrids between Resyn lines and adapted European tester lines. However, the ultimate aim in hybrid breeding is not to maximize heterosis, but to maximize hybrid yield, which is the result of mean parental performance plus heterosis. The observed mean per se performance of Resyn lines was low, regarding yield, oil content, disease resistance, and quality. Therefore, a promising strategy could be to improve the performance of the Resyn gene pool by recurrent selection without reducing its genetic distance from adapted winter rapeseed breeding material.

Acknowledgments The authors thank Gemeinschaft zur Förderung der privaten deutschen Pflanzenzüchtung (GFP) and the German Federal Ministry of Food, Agriculture and Consumer Protection for financial support and Sonja Yaman for the excellent technical assistance.

Open Access This article is distributed under the terms of the Creative Commons Attribution Noncommercial License which permits any noncommercial use, distribution, and reproduction in any medium, provided the original author(s) and source are credited.

\section{References}

Becker HC, Engqvist GM, Karlsson B (1995) Comparison of rapeseed cultivars and resynthesized lines based on allozyme and RFLP markers. Theor Appl Genet 91:62-67

Becker HC, Löptien H, Röbbelen G (1999) Breeding: an overview. In: Gómez-Campo C (ed) Biology of Brassica Coenospecies. Elsevier, Amsterdam, pp 413-460

Dice LR (1945) Measures of the amount of ecological association between species. Ecology 26:297-302

Diers BW, McVetty PBE, Osborn T (1996) Relationship between heterosis and genetic distance based on restriction fragment length polymorphism markers in oilseed rape (Brassica napus). Crop Sci 36:79-83

Falconer DS, Mackay TFC (1996) Introduction to quantitative genetics, 4th edn. Longman, London

Gaeta RT, Pires JC, Iniguez-Luy F, Leon E, Osborn TC (2007) Genomic changes in resynthesized Brassica napus and their effect on gene expression and phenotype. Plant Cell 19:3403-3417

Girke A, Becker HC, Engqvist GM (2001) Predicting heterosis from genetic distances for RFLP markers in resynthesized oilseed rape. In: Quantitative genetics and breeding methods: the way ahead. Proceedings of the 11th Meeting of the Section Biometrics in Plant Breeding, Paris, France, 30.8. - 1.9.2000, pp 257-262

Girke A, Schierholt A, Becker HC (2011) Extending the rapeseed genepool with resynthesized Brassica napus L. I Genetic diversity. Genet Res Crop Evol. doi:10.1007/s10722-011-9772-8

Kebede B, Thiagarajah M, Zimmerli C, Rahmann MH (2010) Improvement of open-pollinated spring rapeseed (Brassica napus L.) through introgression of genetic diversity from winter rapeseed. Crop Sci 50:1236-1243

Knaak C, Ecke W (1995) Genetic diversity and hybrid performance in European winter oilseed rape (Brassica napus L.). In: Proceedings of the 9th International Rapeseed Congress, Cambridge, England, 4. - 7.7.1995, pp 110-112

Lefort-Buson M, Guillot-Lemoine B, Dattee Y (1987) Heterosis and genetic distance in rapeseed (Brassica napus L.): crosses between European and Asiatic selfed lines. Genome 29:413-418

Léon J (1991) Heterosis and mixing effects in winter oilseed rape. Crop Sci 31:281-284

Melchinger AE (1999) Genetic diversity and heterosis. In: Coors JG, Pandey S (eds) Genetics and exploitation of heterosis in crops. American Society of Agronomy, Madison, pp 99-118

Qian W, Meng J, Li M, Frauen M, Sass O, Noack J, Jung C (2006) Introgression of genomic components from Chinese Brassica rapa contributes to widening the genetic diversity in rapeseed (B. napus L.), with emphasis on the evolution of Chinese rapeseed. Theor Appl Genet 113:49-54

Qian W, Li Q, Noack J, Sass O, Meng J, Frauen M, Jung C (2009) Heterotic patterns in rapeseed (Brassica napus L.): II crosses between European winter and Chinese semi-winter lines. Plant Breed 128:466-470

Reif JC, Fischer S, Schrag TA, Lamkey KR, Klein D, Dhillon BS, Utz HF, Melchinger AE (2010) Broadening the genetic base of European maize heterotic pools with US cornbelt germplasm using field and molecular marker data. Theor Appl Genet 120:301-310

Riaz A, Li G, Quresh Z, Swati MS, Quiros CF (2001) Genetic diversity of Brassica napus inbred lines based on sequence-related amplified polymorphism and its relation to hybrid performance. Plant Breed 120:411-415

Rohlf FJ (2000) NTSYS-pc Numerical taxonomy and multivariate analysis system. Version 2.1. Exeter Publishing Co Ltd., Setauket

Rygulla W, Friedt W, Seyis F, Lühs W, Eynck C, von Tiedemann A, Snowdon RJ (2007) Combination of resistance to Verticillium longisporum from zero erucic acid Brassica oleracea and oilseed 
Brassica rapa genotypes in resynthesized rapeseed (Brassica napus) lines. Plant Breed 126:596-602

Seyis F, Fried W, Lühs W (2006) Yield of Brassica napus L. hybrids developed using resynthesized rapeseed material sown at different locations. Field Crops Res 96:176-180

Szadkowski E, Eber F, Huneau V et al (2010) The first meiosis of resynthesized Brassica napus, a genome blender. New Phytol 186:102-112

Tillmann P (1997) The analysis of rapeseed (Brassica napus L.) in a network of NIRS-instruments. CGIRC Bulletin 14:142-147

Udall JA, Quijada PA, Polewicz H, Vogelzang R, Osborn TC (2004) Phenotypic effects of introgressing Chinese winter and resynthe- sized Brassica napus L. germplasm into hybrid spring canola. Crop Sci 44:1990-1996

Utz HF (1991) Plabstat, Computerprogramm zur statistischen Analyse von pflanzenzüchterischen Experimenten, Version 2F. Institut für Pflanzenzüchtung, Saatgutforschung und Populationsgenetik der Universität Hohenheim

Zou J, Zhu J, Huang S, Tian E, Xiao Y, Fu D, Tu J, Fu T, Meng J (2010) Broadening the avenue of intersubgenomic heterosis in oilseed Brassica. Theor Appl Genet 120:283-290 